\title{
Replacement of Hair Cells after Laser Microbeam Irradiation in Cultured Organs of Corti from Embryonic and Neonatal Mice
}

\author{
Matthew W. Kelley, Deepak R. Talreja, and Jeffrey T. Corwin \\ Department of Otolaryngology-HNS and Department of Neuroscience, University of Virginia School of Medicine, \\ Charlottesville, Virginia 22908
}

\begin{abstract}
This study examined the potential for hair cell regeneration in embryonic and neonatal mouse organs of Corti maintained in vitro. Small numbers of hair cells were killed by laser microbeam irradiation and the subsequent recovery processes were monitored by differential interference contrast (DIC) microscopy combined with continuous timelapse video recordings. Replacement hair cells were observed to develop in lesion sites in embryonic cochleae and on rare occasions in neonatal cochleae. In embryonic cochleae, replacement hair cells did not arise through renewed proliferation, but instead developed from preexisting cells that changed from their normal developmental fates in response to the loss of adjacent hair cells. In cochleae established from neonates, lost hair cells usually were not replaced, but 11 apparently regenerated halr cells and a single hair cell labeled by ${ }^{3} \mathrm{H}$-thymidine were observed as rare responses to the creation of hair cell lesions in these organs.
\end{abstract}

The results indicate that the organ of Corti can replace lost hair cells during embryonic and on rare occasions during early neonatal development. The ability of preexisting cells to change their developmental fates in response to hair cell death is consistent with the hypothesis that during embryonic development hair cells may inhibit neighboring cells from specializing as hair cells. In neonatal cultures, the rare occurrence of apparently regenerated hair cells indicates that some cells in the postembryonic organ of Corti retain response mechanisms that can lead to self-repair.

[Key words: cochlea, regeneration, development, hearing, ear, rodent, cell death]

Lost hair cells can be replaced through regeneration in the sensory organs of the lateral lines, the auditory systems, and the vestibular systems of many vertebrates (Stone, 1937; Corwin, 1986; Cotanche, 1987; Corwin and Cotanche, 1988; Ryals and Rubel, 1988; Balak et al., 1990; Weisleder and Rubel, 1992; Forge et al., 1993; Lombarte et al., 1993; Warchol et al., 1993). However, loss of hair cells in the mammalian hearing organ, the organ of Corti,

Received Aug. 23, 1994; revised Oct. 31, 1994; accepted Nov. 4, 1994

We thank Christine Laverack and Arlene Trader for excellent technical assistance. Also, we thank Jim Lechleiter for assistance with confocal microscopy and Tom Reh for use of darkroom and computer facilities during preparation of the final version of the manuscript. This research was supported by grants from NIDCD and the Lions of Virginia Hearing Foundation to J.T.C.

Correspondence should be addressed to Dr. Matthew W: Kelley, Department of Biological Structure, SM-20, University of Washington Health Sciences Center, Seattle, WA 98195.

Copyright 1995 Society for Neuroscience $0270-6474 / 95 / 153013-14 \$ 05.00 / 0$ results in the formation of apparently permanent epithelial "scars" where supporting cells contact each other abnormally at sites where hair cells are missing (Bohne, 1976). Postmortem investigations and the common occurrence of permanent hearing loss in humans and other mammals who have lost hair cells has led to the conclusion that hair cell loss in the organ of Corti is irreversible. The reason for the different regenerative capacities of hair cell epithelia is not understood, but it has been suggested that potential self-repair processes in the organ of Corti may be constrained as a result of the complex cytoarchitecture in that tissue. The highly differentiated cytoarchitecture does not develop until several weeks after birth (Kikuchi and Hilding, 1965; Sher, 1971; Lim and Rueda, 1992). Therefore, as a first step toward evaluating the potential for self-repair in the organ of Corti we performed a series of experiments to assess the potential for more complete recovery after limited loss of hair cells produced experimentally at early stages in development, prior to the complete differentiation of its cytoarchitecture.

Hair cells in organ cultures of the organ of Corti from embryonic and neonatal mice were killed individually by laser microbeam irradiation. Then the responses of the remaining cells in the tissue were followed through ${ }^{3} \mathrm{H}$-thymidine autoradiography, and through histological examinations and time-lapse microscopy. The results demonstrate that the developing cochlear sensory epithelium has a limited ability to produce replacement hair cells during early development and that replacement hair cells develop in response to the death of nearby hair cells under some circumstances.

A preliminary report of these findings was presented at the 17 th annual meeting of the Society for Neuroscience (Kelley et al., 1991).

\section{Materials and Methods}

Embryonic and neonatal cochleae were established in vitro by methods that have been described in greater detail elsewhere (Sobkowicz et al., 1975, 1993; Kelley et al., 1993). Timed-pregnant ICR mice or newborn ICR mouse pups were killed by cervical dislocation on gestational days 14 (E14), 15 (E15), and 16 (E16), or on postnatal day 0 (day of birth $=\mathrm{P} 0$ ), P1, and P2. Individual embryos or newborn mouse pups were placed in sterile HEPES-buffered Hanks balanced saline (HHBS) and staged according to the normal tables of Theiler (1972). The two cochleae were isolated, and the stria vascularis was removed from each to expose the developing organ of Corti, which was cut into basal and apical halves. Both halves were placed on a $45 \times 50 \mathrm{~mm}$ cover glass that had been coated with Cell-Tak (Collaborative Research). The explants were covered with $100 \mu \mathrm{l}$ of culture medium, sealed into Rose chambers, and maintained at $35^{\circ} \mathrm{C}$. Subsequent media changes were made every $48 \mathrm{hr}$

The culture medium contained $20 \%$ horse serum, $10 \%$ mouse embryo extract, and 70\% minimun essential medium (MEM) with Earle's salts, $10 \mathrm{~mm}$ HEPES, $5 \mathrm{~mm}$ L-glutamine, $26 \mathrm{~mm}$ sodium bicarbonate, 15 
units $/ \mathrm{ml}$ penicillin, and $0.09 \mathrm{mg} / \mathrm{ml}$ amphotericin $\mathrm{B}$ at $\mathrm{pH}$ 7.3. MEM, horse serum, penicillin, and amphotericin B were obtained from GIBCO/Bethesda Research Labs. Mouse embryo extract was produced as descrihed in Kelley et al. (1993).

Cells were killed on an inverted microscope by using an ultraviolet (337 nm) laser microbeam. The laser microbeam apparatus consisted of a pulsed, nitrogen gas laser with a peak energy output of $360 \mu \mathrm{J}$ (Laser Science, Inc.), simple lenses, and a beam steering device mounted on an optical rail, so that it directed the laser output through the epifluorescence port of the microscope (Zeiss Axiovert) to the back aperture of a $100 \times, 1.25 \mathrm{NA}$, glycerin-immersion, quartz objective lens (Balak et al., 1990). Single pulses from the laser passed through the apparatus gated by an electronic shutter, and the beam was focused by the $100 \times$ objective to a $1 \mu \mathrm{m}$ or smaller spot. Individual cells were killed by focusing a pulse of the microbeam in the cell nucleus or just beneath the cell's apical surface. After hair cells had been killed, the focus was adjusted and the laser beam was used to make a row of small chips in the coverglass which pointed to the lesion site and facilitated the relocation of the lesion.

In order to determine whether the response of the cochlear epithelium changed as it developed, lesions were made in cultured cochlea at stages equivalent to E15, E16, E17, E18, E20, P0, P1, and P2. The differentiation of the organ of Corti proceeds in a basal-to-apical gradient (Sher, 1971; Lim and Anniko, 1985), so lesions were made in both the basal and apical halves of the organ of Corti. Both inner and outer hair cells were ablated.

In most cases, the response of the epithelium to cell loss was monitored through daily observations via differential interference contrast (DIC) microscopy. During the daily observations, photographs of the lesion site were taken at several levels of focus. In four cases, the lesion sites were photographed every $2 \mathrm{hr}$ during the first $24 \mathrm{hr}$ after the laser treatment, and cvery 4-6 hr during the subsequent $24-48 \mathrm{hr}$. The undamaged cells surrounding the lesion site were positioned in exactly the same location for each photograph so that any changes in the lesion site could be compared over time. Cultures were allowed to recover for up to $6 \mathrm{~d}$ and then fixed. In cultures that were allowed to recover, a second laser lesion was made a specific distance (determined by counting cells) from the recovered lesion just prior to fixation of the tissue, so as to facilitate the microscopic relocation of the site of the recovered lesion. Cultures were fixed overnight in $2.5 \%$ glutaraldehyde in $0.1 \mathrm{M}$ phosphate buffer at $\mathrm{pH} 7.3$ immediately after the second laser lesion was made. Samples were placed in glycerol and water $(9: 1)$ and analyzed as whole-mounts.

In order to determine whether the epithelial response to cell loss included proliferation of the surviving cells, ${ }^{3} \mathrm{H}$-methyl-thymidine was added to 18 cultures (four embryonic and 14 neonatal) at $1.0 \mu \mathrm{Ci} / \mathrm{ml}$ (specific activity, $60 \mathrm{Ci} / \mathrm{mm}$; ICN Biomedicals) immediately after the laser irradiation. Medium changes were made every $48 \mathrm{hr}$ and included $1.0 \mu \mathrm{Ci} / \mathrm{ml}^{3} \mathrm{H}$-thymidine.

For three separate lesions, the responses of the epithelia were monitored continuously by time-lapse video microscopy after hair cells had been killed by the laser microbeam. Immediately following laser irradiation, individual cultures were placed on an inverted microscope that was equipped with an incubator maintained at $35-37^{\circ} \mathrm{C}$. The lesion site was visualized using a $100 \times, 1.25 \mathrm{NA}$, oil-immersion objective and a video camera (Hamamatsu, model 2400). At $2 \mathrm{~min}$ intervals video images were summed into the frame buffer of an IMAGE-1/AT processing system (Universal Imaging). Each summed image was enhanced by recalculating the gray scale to optimize contrast, and by convolution with a sharpening kernel to enhanced edge contrast. After enhancement, each image was recorded on a black and white optical memory disk recorder (Panasonic 2028). In order to monitor the responses of cells located in the depth of the tissue beneath each lesion site, several different planes of focus were sampled in time-lapse recordings made concurrently at different depths in the epithelium through the use of a stepper-motor which automatically changed the z-axis position of the objective lens to a set of programmed positions. The amount of time that the cultures were exposed to the light and heat generated by the microscope illuminator was minimized by placing an electronic shutter in the light path of the condenser. The IMAGE-1/AT program controlled both the stepper-motor and the shutter.

Individual cultures were transferred to the time-lapse apparatus immediately after laser irradiation. A continuous video record of epithelial recovery was generated until the characteristic pattern of hair cells and supporting cells once again became evident at the site of the lesion, usually $30-72 \mathrm{hr}$ after the laser treatment. The relocation of the recovered lesion sites was facilitated by making a second set of laser lesions just prior to fixation and analysis of whole-mounts, as described above.

In order to determine whether the response of the epithelium to the loss of hair cells included lateral movements of the surrounding undamaged cells, 16 fixed cochleae with a total of 34 lesions were prepared as whole-mounts. Cytocochleograms that charted the positions of all hair cells were traced at $63 \times$ using a microscope equipped with a drawing tube. Using the cytocochleograms it was possible to determine whether there was a decrease in the packing density of hair cells near the lesion sites.

After cytocochleograms were generated, those same specimens were postfixed in $1 \% \mathrm{OsO}_{4}$ in $0.1 \mathrm{M}$ phosphate buffer at $\mathrm{pH} 7.3$ for $1 \mathrm{hr}$. They were then dehydrated through a graded ethanol series, and embedded in methacrylate (Historesin, Leica). In order to observe changes in the epithelium related to recovery, specimens were sectioned at 3 mm thickness in either a transverse or a tangential plane. Slides containing sections from cultures that had been maintained in medium with tritiated thymidine were dipped in Kodak NTB2 nuclear track emulsion, allowed to expose in the dark for 8-10 d, and then developed for autoradiography according to a published procedure (Corwin, 1985).

To examine the response of supporting cells bordering lesion sites, filamentous actin was labeled with rhodamine-conjugated phalloidin in 27 cochleae (Wulf el al., 1979). Specimens were fixed for $1 \mathrm{hr}$ in $4 \%$ paraformaldehyde, washed in PBS, and then permeabilized in $0.1 \%$ Triton X-100 in PBS for 10 min. After washing in PBS, specimens were incubated in $50 \mu \mathrm{g} / \mathrm{ml}$ rhodamine-conjugated phalloidin (Sigma Chemical Co.) in PBS for $45 \mathrm{~min}$ at room temperature. They were then washed in PBS and mounted on microscope slides in glycerin and water (9:1).

The morphology of stereociliary hair bundles on hair cells located adjacent to lesion sites was examined for two different cochleae using confocal microscopy. Images of phalloidin-stained samples were obtained on a Bio-Rad MRC 600 with an inverted microscope and a $100 \times$, 1.25 NA objective. For each bundle or group of bundles that was examined, eight video frames were summed at 56 different levels of focus beginning at the apex of the stereociliary bundle and moving progressively downward at $0.8 \mu \mathrm{m}$ intervals to the apical surface of the hair cell epithelium. The video images were then integrated to generate a three-dimensional view of the stereociliary bundles.

\section{Results}

\section{Laser microbeam lesions}

Cochlear cultures survived and developed normally for at least $10 \mathrm{~d}$. Explants adhered to the Cell-Tak substrate and flattened within 12 hr. The developing sensory epitheliun is located along the outer edge of the explant, so the flattening of the culture organs made it possible to obtain high-resolution images of the developing hair cells and supporting cells in the living tissue. The tissue appeared normal as assessed through examination of surface preparations and plastic sections cut in tangential or transverse planes.

The organ of Corti is characterized by a highly ordered pattern of sensory cells. A single row of inner hair cells and three or four rows of outer hair cells extend along its length. In addition, supporting cells located at the basal surface of the sensory epithelium extend processes that interdigitate with the hair cells to form a rigorous geometric pattern. In mice, the formation of this pattern is initially identified between E15 and E17 by the development of four rows of cells that will differentiate as the single row of inner hair cells and three rows of outer hair cells. These rows of cells are closely opposed initially, but as the organ continues to develop, the maturation of the pillar cells which are located hetween the inner hair cells and first row of outer hair cells forces a separation between the inner and outer hair cells (Fig. 1). The development of this geometric pattern of hair cells and supporting cells facilitated the analysis of epithelial recovery. After $4 \mathrm{~d}$ in culture, cochlear explants that were established between embryonic day 14 (E14) and embryonic day 20 (E20) developed a normal sensory epithelium with a single row of 

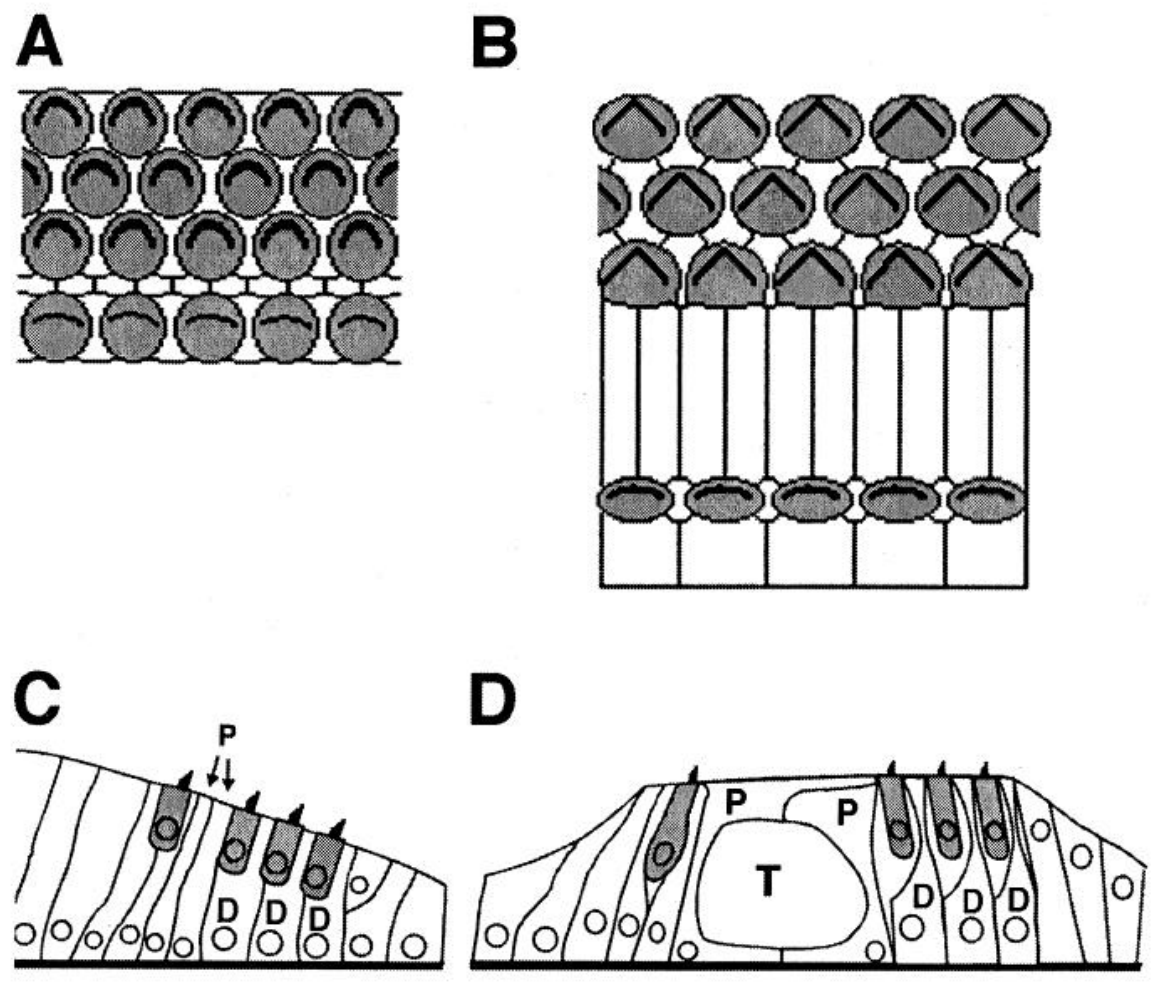

Figure 1. Schematic illustration of the organ of Corti. A, Tangential view of the sensory epithelium on P0. The apical surfaces of the hair cells are shaded. Heavy lines indicate stereociliary bundles. Inner hair cells are located at the bottom of the figure. Note the close apposition of the inner and outer hair cells. $B$, Tangential view of the sensory epithelium in an adult. The expansion of the pillar cells has caused an increase in the distance between the inner and outer hair cells. $C$, Transverse view of the sensory epithelium on P0. Hair cell bodies are shaded. The inner hair cell is located on the left side of the figure. Note that the pillar cells $(P)$ and Deiter's cells $(D)$ are present but have not developed their mature phenotypes at this stage. $D$, Transverse view of the sensory epithelium in an adult. The pillar cells and Deiter's cells have differentiated to form the tunnel of Corti $(T)$ and the spaces of Nuel, respectively. Drawings are not to scale.

inner hair cells and three or four rows of outer hair cells. The pattern and spacing of hair cells and supporting cells appeared normal and regular (Fig. 2).

The ultraviolet laser beam was effective for killing cells. The available energy per pulse was usually more than sufficient to kill a cell. In most cases it was necessary to attenuate the beam by $20-60 \%$ in order to prevent damage to the surrounding cells. When pulses were given in the range of the minimum energy level required to kill a hair cell, the irradiated cells were extruded from the epithelium within $2 \mathrm{hr}$ (Fig. 3). After laser treat- ments at higher energy levels, the treated hair cells were extruded within $2 \mathrm{~min}$. For each culture, the approximate minimum energy required to kill a single hair cell was determined by making test treatments in a remote region of the sensory epithelium that subsequently was not monitored for hair cell recovery. In each case, the entire cell was extruded from the epithelium regardless of whether the laser beam had been focused on the nucleus or just beneath the apical surface (Fig. 3). Microbeam irradiation resulted in the death of single cells, so that the number of cells that were damaged by the laser beam was limited

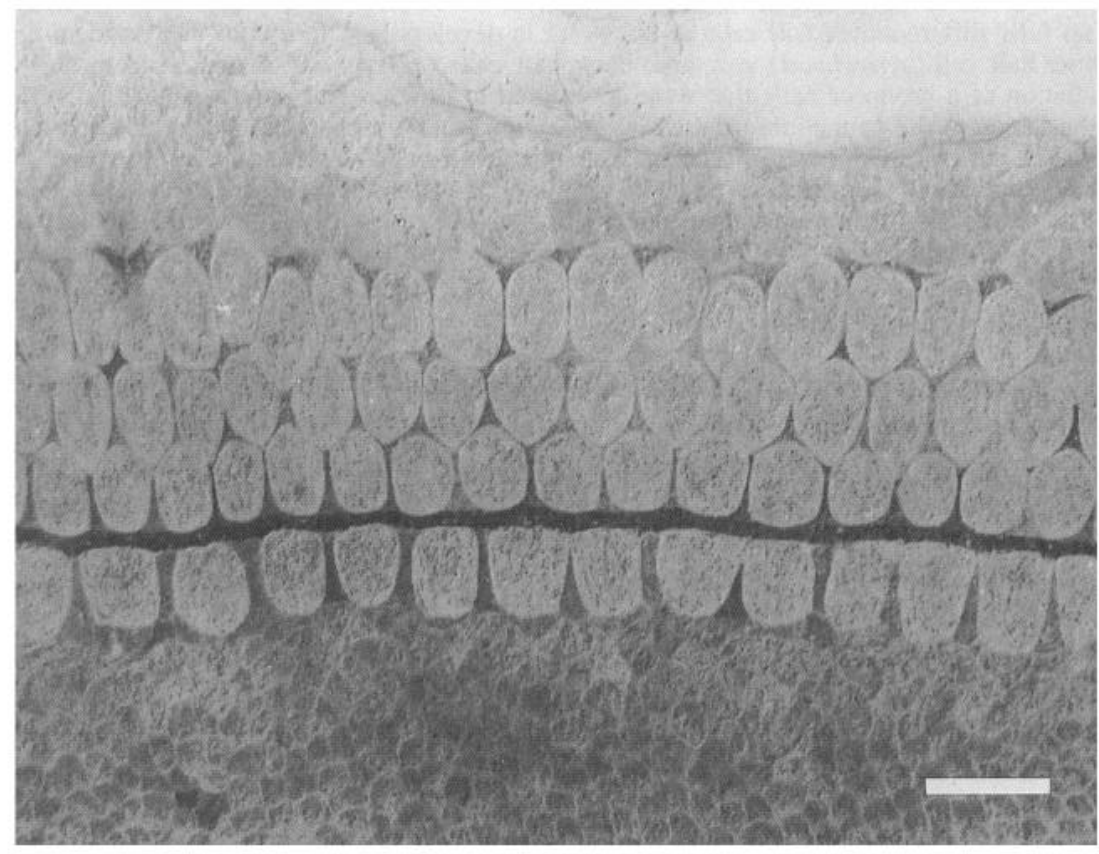

Figure 2. Tangential section through the sensory epithelium from a cochlear culture established on E14 after $6 \mathrm{~d}$ in vitro. A single row of inner hair cells and three rows of outer hair cells are visible. Scale bar, $10 \mu \mathrm{m}$. 

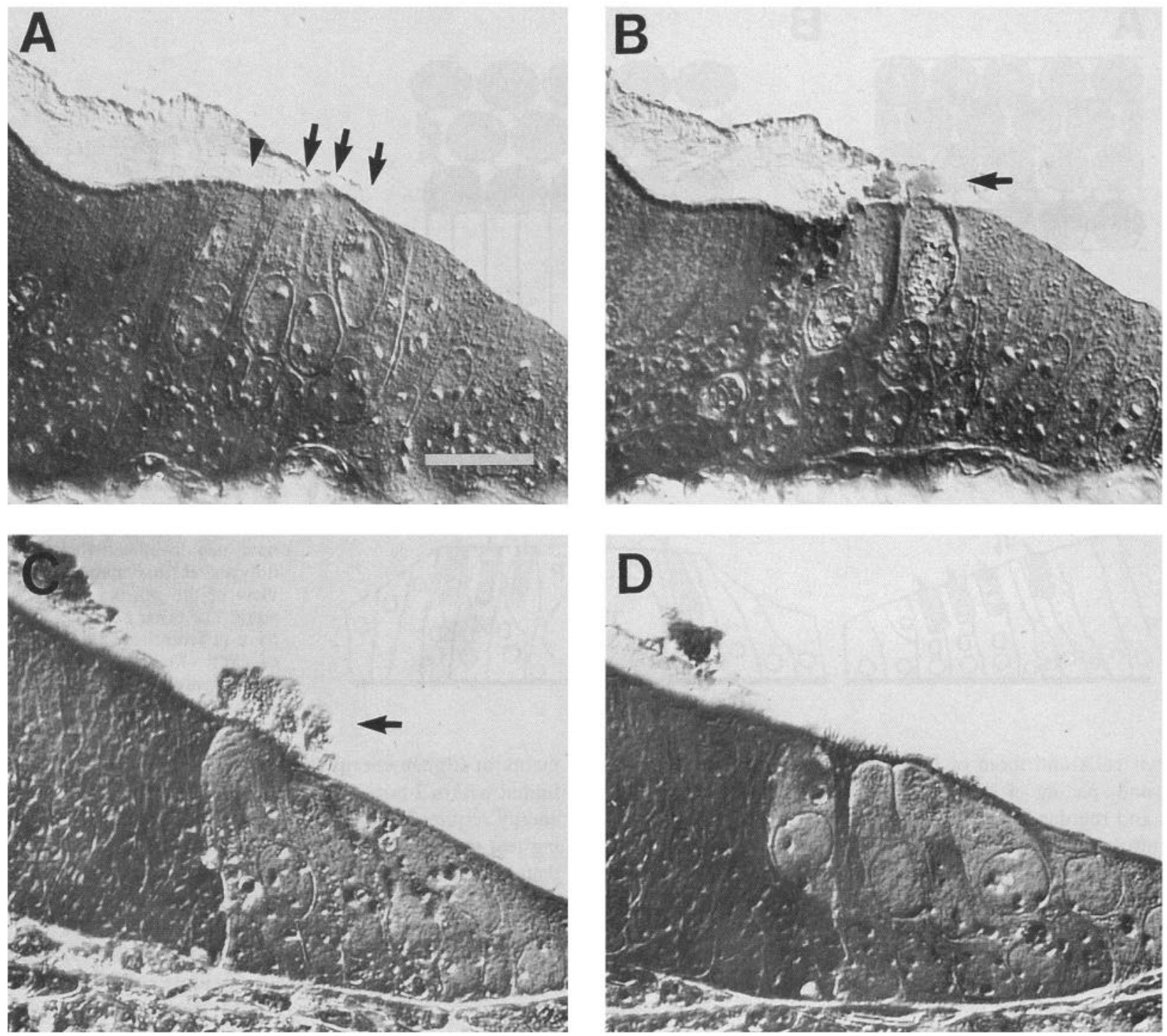

Figure 3. Hair cell death and extrusion after laser irradiation. A, Transverse section through the developing sensory epithelium of an E13 cochlear explant after $3 \mathrm{~d}$ in culture. Although there are no fully differentiated hair cells at this point in development, four cells can be identified that have become committed to differentiate as a single inner hair cell (arrowhead) and three outer hair cells (arrows). B, A section from the same culture as in $A$, which was fixed $15 \mathrm{~min}$ after laser irradiation of a group of cells that were committed to differentiate as hair cells. The cytoplasm from some of these irradiated cells has extruded into the lumen of the epithelium (arrow). $C$, A section from a second explant established from the same litter of pups as in $A$ and $B$. In this region, the developing hair cells were irradiated $6 \mathrm{hr}$ prior to fixation. There is a large amount of cell debris located on the apical surface, and there are no cells that can be identified as developing hair cells in the epithelium. $D$, A section from the same culture as in $C$, but from a region that was not irradiated. The separation between sections $C$ and $D$ is less that $20 \mu \mathrm{m}$. Note that the epithelium appears undamaged, and the cells that will develop as a single inner hair cell and three outer hair cells can be identified. Scale bar, $20 \mu \mathrm{m}$ for $A-D$.

to just those hair cells that were intentionally irradiated. Histological analysis showed that lesioned regions and undamaged regions of the sensory epithelia had only one clearly distinct difference: the loss of the irradiated hair cells, even though they were separated by as little as $20 \mu \mathrm{m}$ (Fig. 3C,D).

The lesion sites were usually relocated even after several days by finding the rows of chips that had been made in the underlying coverglass for that purpose. In some cases, the sensory epithelium, including the lesion site, would move slightly over time as a result of the flattening of the culture. In those cases, the movement of the sensory epithelium occurred progressively, so it was still possible to relocate the lesion sites. Debris from the extruded cells often remained above the apical surface of the lesion for several days after the laser irradiation and could serve as an additional landmark for relocating the lesion. In most cases, the cell debris was gone from the apical surface of the culture by 2-3 d after extrusion of the laser-treated cells. The time-lapse recordings showed that the debris from the extruded cells was phagocytosed by motile cells that were present in the explant at the time that it was established. We presume that the phagocytic cells were activated macrophages.

\section{Recovery of the sensory epithelium in embryonic organs of Corti}

In living cultures that were viewed by DIC microscopy, it was possible to identify the band of cells that would develop as either 
Table 1. Summary of all laser ablations in which recovery of the lesion site was observed

\begin{tabular}{lll} 
Hair cell type & $\begin{array}{l}\text { Time since identification } \\
\text { of individual hair cells }\end{array}$ & $\begin{array}{l}\text { Index of } \\
\text { lateral sliding }\end{array}$ \\
\hline Outer hair cells (16) & $<48 \mathrm{hr}$ & $0.13 \pm 0.06$ \\
Outer hair cells (8) & $48 \mathrm{hr}$ & $0.60 \pm 0.18$ \\
Outer hair cells (11) & $>48 \mathrm{hr}$ & $1.00 \pm 0.0$ \\
Inner hair cells (14) & $<48 \mathrm{hr}$ & $1.00 \pm 0.0$ \\
\hline
\end{tabular}

Lesion sites are divided into categories based on position and timing of the lesion. Number of samples for each condition is in parentheses. The index of lateral sliding is a measure of the degree of lateral sliding of the cells surrounding an individual lesion site. A score of 1.00 indicates that the lesion site was completely repaired through lateral sliding. A score of 0.00 indicates that no lateral sliding was observed, indicating that the lesion was repaired through the development of replacement hair cells. Values for index of lateral sliding are mean $\pm \mathrm{SE}$

hair cells or supporting cells by E14 in the basal half of the explant and by E15 in the apical half. By E15, individual cells that had become committed to specific differentiation as hair cells could be identified in the basal halt of each explant. In the apical half of the cochlea, individual cells that were committed to differentiate as hair cells could be identificd by E17. Committed hair cells were recognizable because of an increase in the diameter of their nuclei, which were also more spherical than the nearby nuclei. They also came to occupy apical positions in the epithelium, which was most easily observed by noting the position of the nucleus (Fig. 3A). Initially, we attempted to kill cells that would differentiate as hair cells as soon as possible after it was determined that they had become commilted to the hair cell phenotype. In subsequent experiments, the timing of the laser irradiations was delayed in order to determine whether the response of the epithelium changed as it progressed to later stages in development. In each of the experiments, lesions were made by irradiating either three inner hair cells and five or six adjacent outer hair cells or nine outer hair cells, three each in three adjacent rows, without irradiation of inner hair cells. A total of 34 different lesions from 16 separate cochleae were analyzed in this portion of the study.

The response of the epithelium to the loss of cells that had become committed to the hair cell phenotype differed depending on whether the killed cells had been committed to differentiate as inner hair cells or outer hair cells. The responses to the loss of the two types of cells will be addressed separately.

\section{Outer hair cells}

The response of the epithelium to the death of outer hair cells changed progressively with development. If the cells were killed during the first $48 \mathrm{hr}$ after they became identifiable as committed hair cells (E15-E17 in the basal half of the cochlea, E17-E19 in the apical half), then the recovery of the epithelium included the appearance of new replacement hair cells in the lesion site (Table 1). However, if committed outer hair cells were killed more than $48 \mathrm{hr}$ after the point in development when the individual committed outer hair cells could be identified at that location, then the recovery of the epithelia consisted primarily of lateral movements of the untreated hair cells remaining at the edges of the lesion.

The time course of epithelial recovery was consistent among cases for all of the lesions made during the first $48 \mathrm{hr}$ period after committed outer hair cells were recognizable. Within 6-8 hr of laser irradiation, the laser-treated hair cells had been completely extruded from the epithelium (Figs. 3, 4C). After that time, no hair cell bodies or hair cell nuclei were present at the site of the lesion. Other cell bodies and the cell nuclei deeper in the epithelium, below the lesion, were still present and appeared undamaged (Fig. 3C). By $24 \mathrm{hr}$ after laser irradiation, cells that appeared similar to committed hair cells were observed at the site where the lesion had becn made (Fig. 4E). Although distinct breaks in the patterns of developing outer hair cell surfaces and nuclei were still apparent, a few new cells became clearly recognizable at the site of the lesion. Between 24 and 72 hr post-irradiation, the number of cells in the lesion sites progressively increased until the normal number and the normal pattern of developing outer hair cells had been completely restored (Fig. 4G). In some cases, the initial positions of replacement outer hair cells that formed during the recovery process did not match the pattern of surrounding hair cells, but as recovery continued these cells appeared to shift into appropriate positions. By 72-96 hr, the replacement hair cells closely resembled neighboring outer hair cells in the size and position of their nuclei and in the development of their stereociliary bundles (Figs. 4, 5).

The replacement outer hair cells that appeared in the lesion sites could have arisen via the development of new outer hair cells or via lateral movements of outer hair cells from outside the lesion. If the source of replacement outer hair cells was lateral movement of existing hair cells, then this effect would necessarily cause a decrease in the density of outer hair cells in regions surrounding the lesion site. To determine whether lateral movement of surrounding hair cells played a role in recovery, the measured density of hair cells through each lesion sitc was compared with the predicted density change for recovery of that lesion through lateral sliding alone. The calculated change in hair cell density was plotted with a normal distribution over the length of the lesion site. For 15 out of 22 lesions made within $48 \mathrm{hr}$ of identification of individual committed hair cells there was no decrease in the packing density of outer hair cells. This suggested that new, replacement hair cells had developed at the site of the lesion (Fig. 6A, Table 1). For four of the 22 lesions made within the first $48 \mathrm{hr}$, there was a decrease in the spatial density of hair cells, but in each case the decrease was not equivalent to the calculated density change that could have resulted exclusively from rearrangements in the positions of surviving hair cells that neighbored the lesion. This suggests that some replacement hair cells developed in each of these lesions (Fig. $6 B)$.

For three of the 22 lesions madc in the first $48 \mathrm{hr}$, and for 13 out of 13 lesions made later in development, more than $48 \mathrm{hr}$ after committed hair cells were recognizable, only a few hair cells were observed in the lesion site after the recovery period. Measurements of the packing density of outer hair cells through those lesion sites strongly correlated with the density changes predicted from a shift in the positions of surviving hair cells. In the lesions made at those later stages in development it seems likely that the observed recovery was the result of lateral sliding of surrounding hair cells into the site of the lesion (Fig. 6C).

In order to determine whether replacement outer hair cells arose from renewed proliferation within the epithelium, the mitotic tracer tritiated thymidine was added to the medium in four separate cultures. Two separate lesions were made in each culture (eight lesions total) during the first $48 \mathrm{hr}$ period in vitro, and then the cultures were incubated in medium containing tri- 

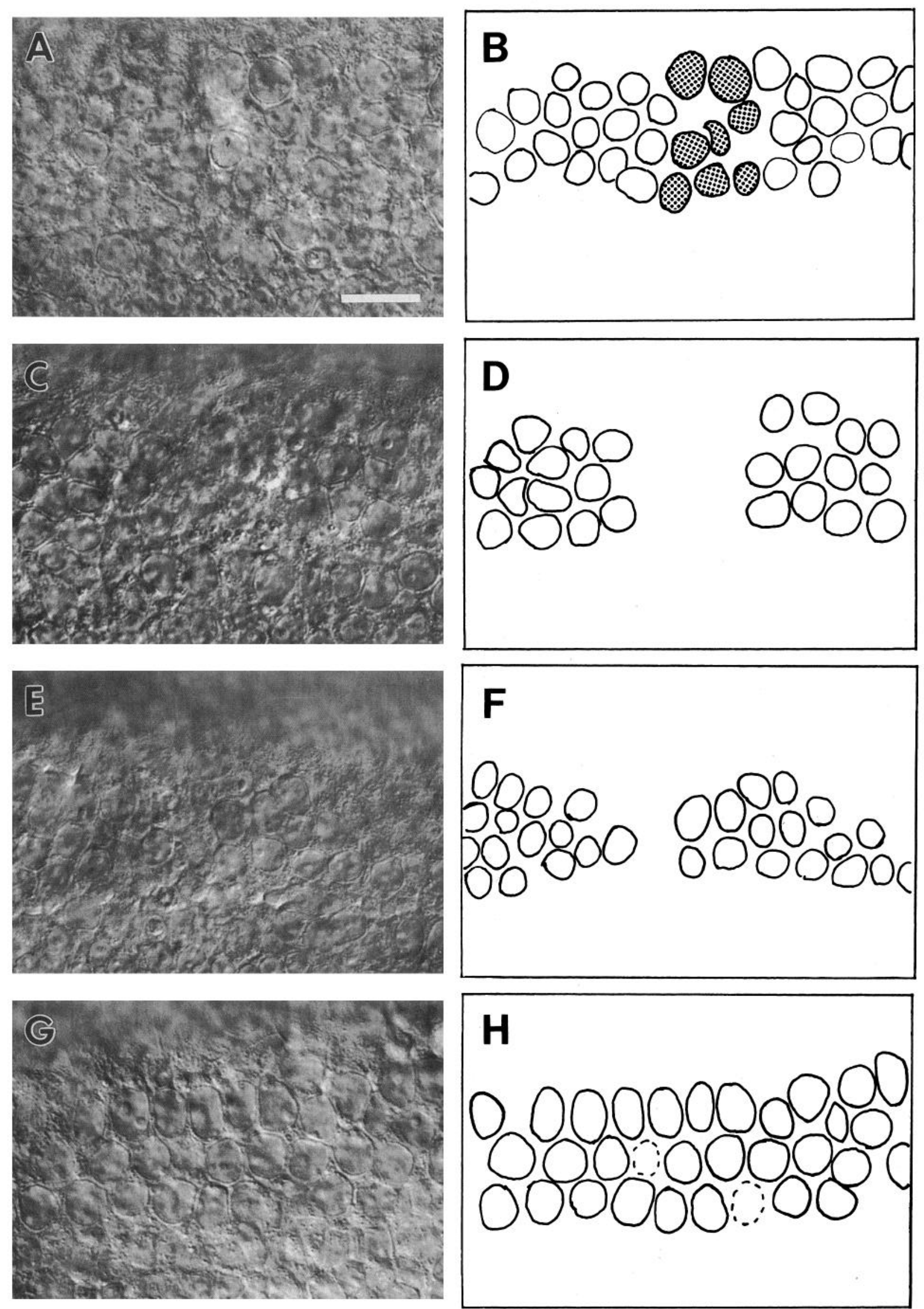

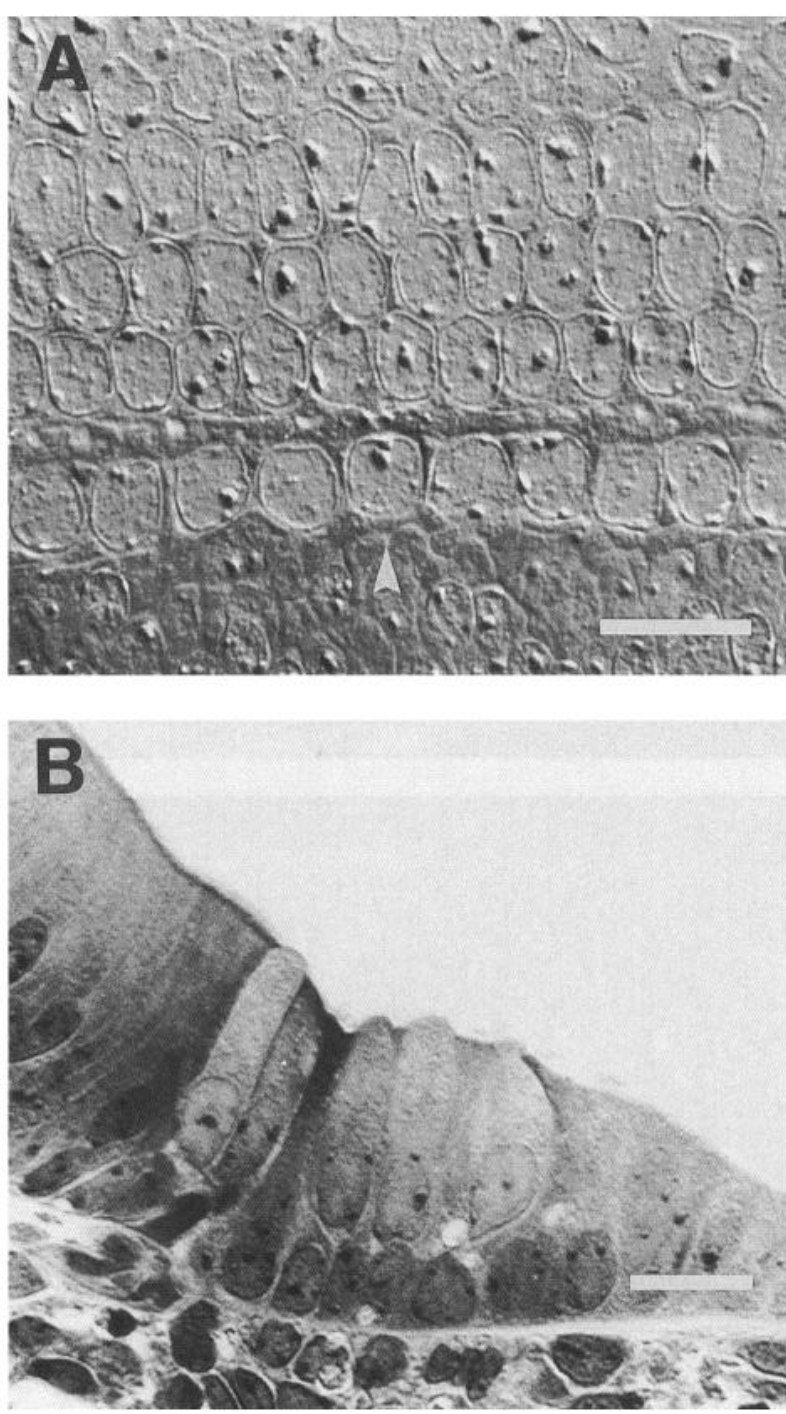

Figure 5. Recovery of the sensory epithelium after hair cell ablation. A, A tangential section through the organ of Corti $72 \mathrm{hr}$ after the laser irradiation of three inner hair cells and five outer hair cells. The center of the lesion site is indicated by the arrowhead. Although there appears to be a slight disruption in the rows of outer hair cells, there is no evidence of a deficit in the number of hair cells. $B$, A transverse section through a comparable lesion site $72 \mathrm{hr}$ after laser irradiation. In this section there are three outer hair cells and one inner hair cell, as well as a possible second inner hair cell. The double inner hair cells were observed in the sample as a whole-mount first, then the tissue was embedded and oriented so that the plane of section would be radial to the epithelium in this region. See text section on recovery of embryonic inner hair cells for details. Scale bars: $A, 20 \mu \mathrm{m} ; B, 10 \mu \mathrm{m}$.

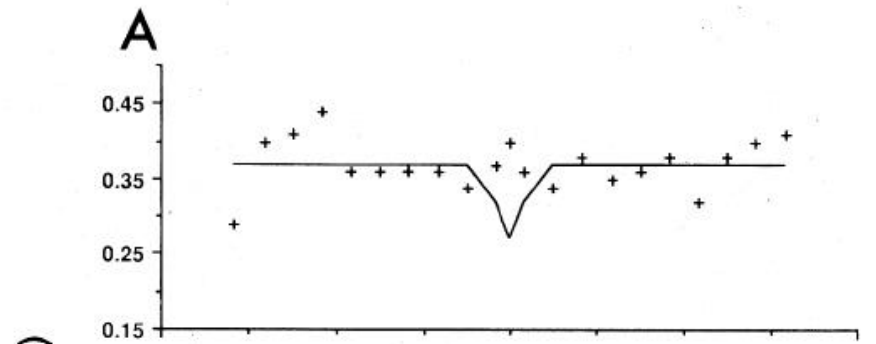

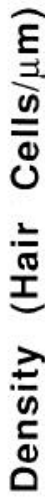
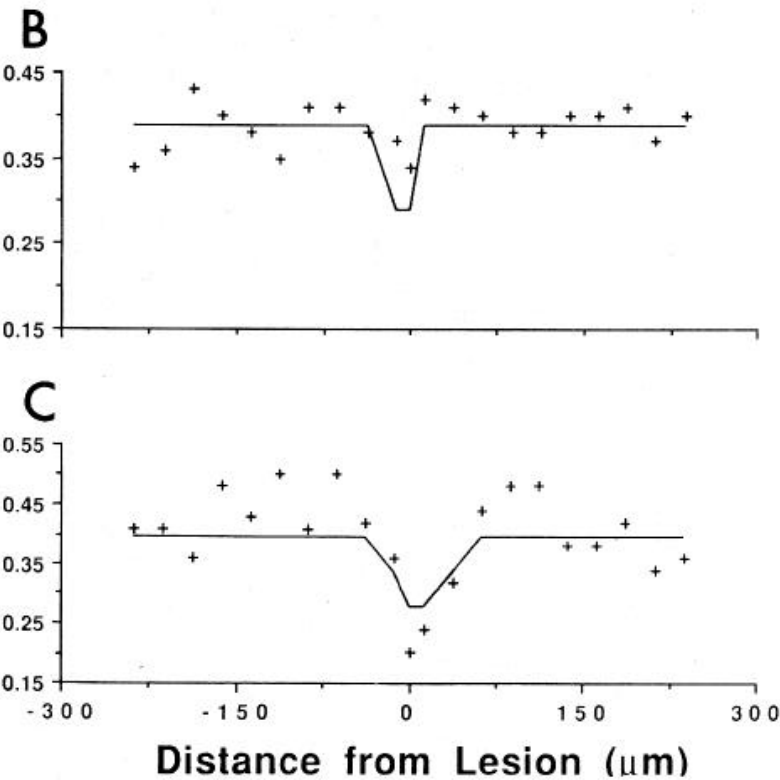

Figure 6. Density measurements for the three different observed responses of the epithelium to the laser irradiation of developing outer hair cells in the basal half of the cochlea. A, Density of outer hair cells $72 \mathrm{hr}$ after laser irradiation of five outer hair cells on E15. Each "+" represents the density of hair cells per micrometer for a $25 \mu \mathrm{m}$ bin. The solid line represents the calculated changes in outer hair cell densities if the repair of the lesion site occurred through lateral sliding of the remaining hair cells. Note that the density of hair cells actually increased in the center of the lesion site. $B$, Response of the epithelium after $72 \mathrm{hr}$ to a second lesion of five outer hair cells made on E15. Note in this case that although there was a decrease in the density of hair cells in the lesion site, this decrease was not equal to the calculated decrease in cell densities that would have occurred if the response of the epithelium had been limited to lateral movement of the remaining cells. $C$, Response of the epithelium $72 \mathrm{hr}$ after killing nine outer hair cells on E17. Note that the decrease in cell density through the lesion site closely matches the calculated changes in density if the response of the epithelium was limited to lateral movement of the surrounding cells.

\section{$\leftarrow$}

Figure 4. Recovery of the developing organ of Corti after laser irradiation of hair cells. A, A DIC image of the developing sensory epithelium from a living cochlear explant established on E13 after $3 \mathrm{~d}$ in culture. The cells that will differentiate as outer hair cells can be identified as a band of rounded cell nuclei that are located closer to the apical surface of the epithelium than are the surrounding nuclei and that are roughly organized into three rows. $B$, A tracing from the micrograph in $A$, illustrating the individual cell nuclei. The stippled circles indicate the group of cells that were killed by laser microbeam irradiation. $C$, The same region of the sensory epithelium $6 \mathrm{hr}$ after laser irradiation. A gap in the band of hair cell nuclei is evident. $D$, A tracing from the micrograph in $C$, illustrating the cells that were ablated by the laser irradiation. $E$, The same region $18 \mathrm{hr}$ after laser irradiation. The size of the lesion site appears to be reduced in comparison with $C$. $F$, A tracing from the micrograph in $E$. Note that the size of the lesion site is reduced and also that there may have been some lateral movement of the cells adjacent to the lesion. $G$, The lesion site approximately $48 \mathrm{hr}$ after irradiation. The epithelium has developed to a point where the three rows of outer hair cell nuclei can be clearly identified. At this point the lesion site appears to have been completely repaired. $H$, A tracing from the micrograph in $G$. The outlines of two cells in the epithelium are dashed to indicate that the nuclei of these cells were located at a slightly lower level of focus. Although not illustrated, this culture was allowed to develop for another $24 \mathrm{hr}$ prior to fixation. At the end of that time, stereociliary bundles could be identified on individual hair cells in the lesion site. Scale bar, $20 \mu \mathrm{m}$ for $A-H$. 

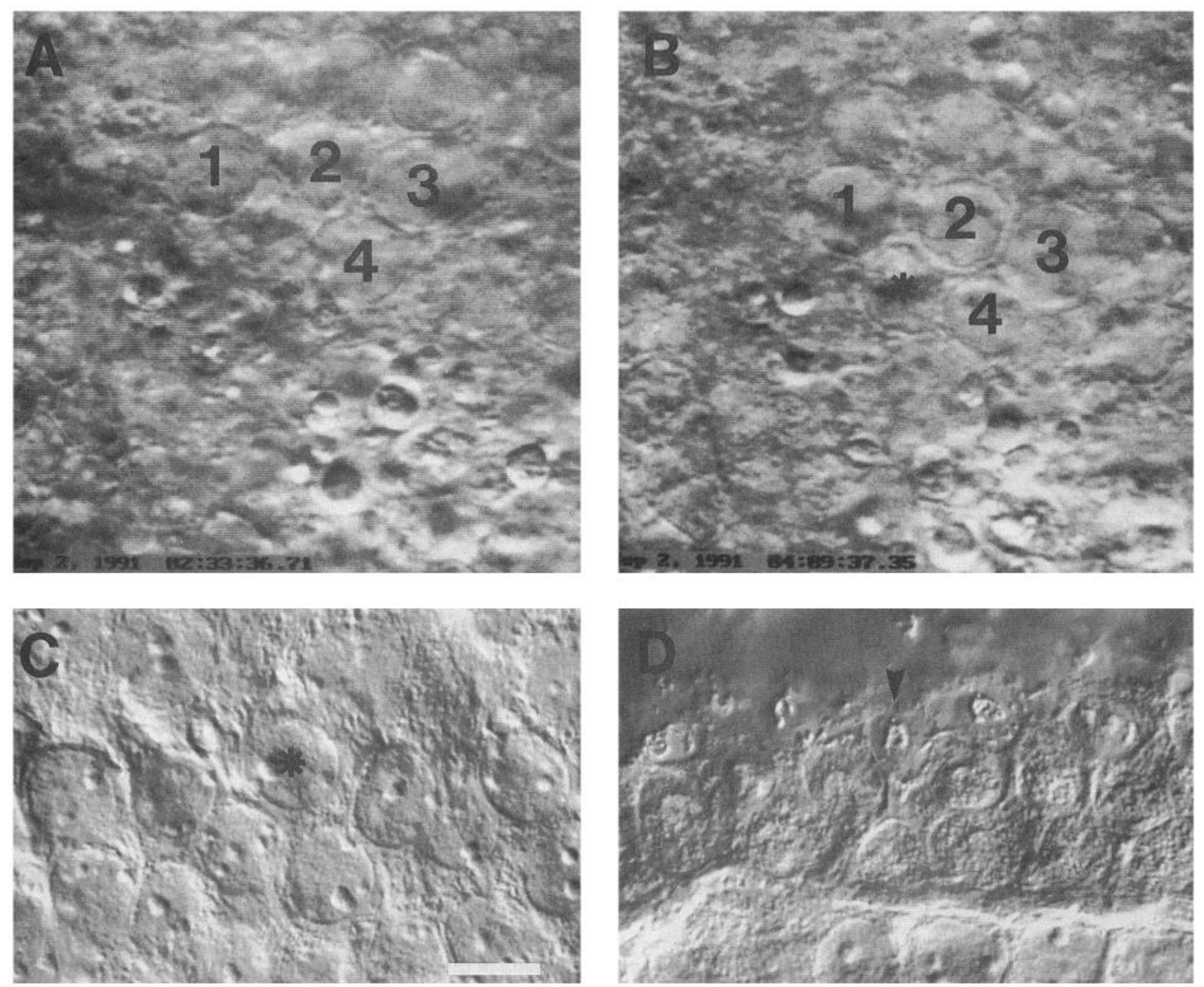

Figure 7. Time-lapse video recording of the recovery of the epithelium after ablating nine outer hair cells in the apical half of the organ of Corti on E17. A, The cells labeled 1-4 are the last four remaining cells on the edge of the lesion site located in the lower half of the micrograph 26 hr after irradiation. $B$, The same region of the epithelium $90 \mathrm{~min}$ after the micrograph in $A$. In addition to the four cells that were present in $A$, a fifth cell (asterisk) has emerged from a lower plane of focus. The newly emerged nucleus closely resembles the existing hair cells in both shape and position. $C$, The same region of the sensory epithelium as in $A$ and $B, 54 \mathrm{hr}$ after the time point in $B$ and a total of $71 \mathrm{hr}$ after laser irradiation. The cell marked with the asterisk is the same cell as in $B$. The cell has moved in the epithelium and now appears to be in the position of third row outer hair cell. $D$, The same region as in $C$, but at a different level of focus. At this level a small stereociliary bundle (arrowhead) can be identified on the apical surface of the marked cell. In $A$ and $B$ the length of the status line is $30 \mu \mathrm{m}$. Scale bar, $10 \mu \mathrm{m}$ for $C$ and $D$.

tiated thymidine for a total of 60-72 hr, as replacement hair cells developed and the structure of the epithelium recovered. Analysis of the autoradiographs for these samples indicated extensive labeling in each culture, with labeling over the nuclei of fibroblasts outside the sensory epithelium and, in some cases, labeling over the nuclei of epithelial cells in a region just proximal to the hair cells, termed the greater epithelial ridge. Labeled cells typically had an average of 30-50 silver grains over each nucleus, while unlabeled cells never had more than three silver grains per nucleus. Within the lesion sites, there was no labeling of either hair cells or supporting cells. The results demonstrated that the replacement hair cells in these four cultures did not arise through renewed proliferation.

One source of replacement hair cells was conclusively identified by making continuous time-lapse video recordings of the response of the epithelium to the loss of outer hair cells in three other cultures. In the first experiment six outer hair cells were killed. For the second and third experiments three and four outer hair cells were killed, respectively. For each sample, a contin- uous time-lapse record of the recovery period was made starting immediately after the laser irradiation and continuing until replacement hair cells could be identified in the site of the lesion. The time-lapse recordings were analyzed after first identifying replacement hair cells that had formed in the lesion sites by way of analysis of the fixed specimens and through examination of the last frames of the video record prior to fixation. Then the origin and the events that led to the development of each replacement hair cell were determined by playing the video record in reverse. A total of 11 outer hair cells developed in the three lesion sites during the periods of time-lapse recording (Fig. 7). For each of these cells, the nucleus was observed to appear in the lesion site as a result of apically directed movement of the nucleus from a starting position deeper in the epithelium. The analysis depended on the ability to image several planes of depth through the sensory epithelium in the concurrent time-lapse recordings. At approximately the same time that these replacement cell nuclei appeared at the more apical level that is characteristic of the hair cell nuclei, corresponding images of cell nuclei were 


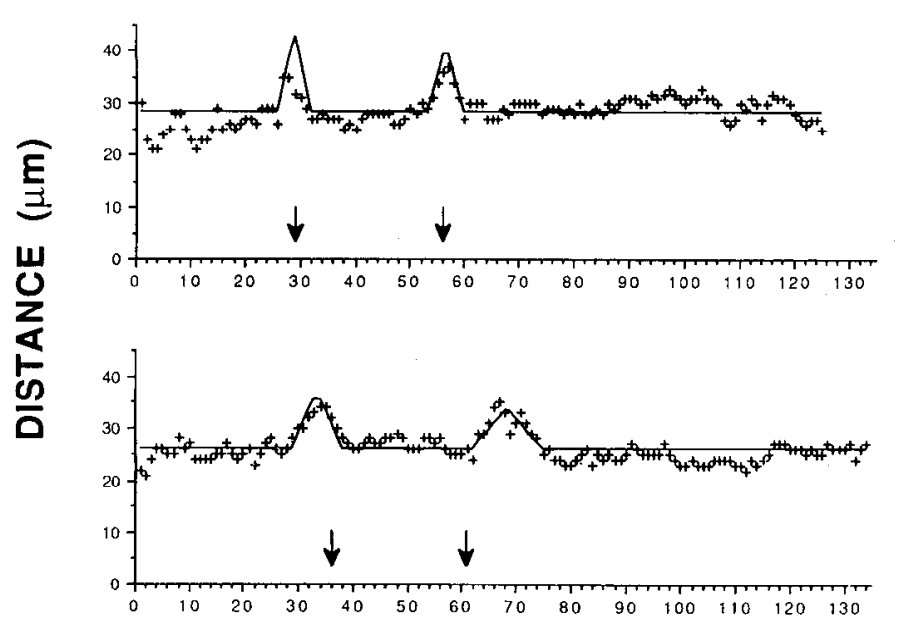

INNER HAIR CELL NUMBER

Figure 8. Changes in internuclear distances after laser irradiation of inner hair cells. Three inner hair cells were ablated at the position of each arrow in two different organ of Corti cultures on E15. Internuclear inner hair cell distances were measured along the entire length of the each cochlea after $72 \mathrm{hr}$ of recovery and plotted as "+"s. The solid lines represent the calculated changes in internuclear distances that would be required to fill the lesion siles through lateral sliding of the remaining hair cells. Note that in each lesion site the measured changes in internuclear distance closely match the calculated changes.

observed to disappear from a nuclear layer in the time-lapse records made at a deeper plane of focus. Before they began their upward movement in the cpithclium, the nuclei of these cells appeared smaller than the nuclei of hair cells. Their positions were consistent with the positions of nuclei in surrounding cells that would be expected to differentiate as supporting cells. However, once these cells had moved upward in the epithelium, their nuclei became more spherical and increased in diameter. The cells that contained those nuclei soon began to develop the characteristic morphology of hair cells, including small apical hair bundles (Fig. 7D).

Time-lapse observations in the basal half of one organ of Corti culture at a developmental time equivalent to approximately E17 suggested that cell death may have occurred in the depth of the sensory epithelium at that time. During this time period, a group of cells located beneath the developing hair cells appeared to be degenerating. These cells developed a large number of vacuoles within their cytoplasm and the nuclear membranes of these cells appeared to be breaking down. Finally, these cells appeared to lyse. The appearance of these cells was similar to the appearance of dying cells that had been observed in previous time-lapse records. Within $24 \mathrm{hr}$ of the specific observation of those apparently dying cells, they could no longer be identified in the tissue. Over the same time period, the overall health of the culture appeared to be good. Review of the timelapse records indicated that a decrease in the thickness of the developing sensory epithelium from $3-4$ cell layers to only two cell layers coincided with the disappearance of the apparently unhealthy cells.

\section{Inner hair cells}

When inner hair cells were killed by the microbeam, replacement hair cells did not appear to develop in any lesion sites, even in cases where inner hair cells were killed at the earliest
Table 2. Total number of hair cell lesions in organ of Corti cultures established from neonatal animals

\begin{tabular}{|c|c|c|c|c|}
\hline \multirow{3}{*}{$\begin{array}{l}\text { Hair cell } \\
\text { type and } \\
\text { number }\end{array}$} & \multicolumn{4}{|c|}{ Recovery time } \\
\hline & \multicolumn{2}{|l|}{$48 \mathrm{hr}$} & \multicolumn{2}{|l|}{$>48 \mathrm{hr}$} \\
\hline & \# of lesions & $\begin{array}{l}\text { \# of reg. } \\
\text { hair cells }\end{array}$ & \# of lesions & $\begin{array}{l}\text { \# of reg. } \\
\text { hair cells }\end{array}$ \\
\hline $5 \mathrm{IHC}$ & 33 & 0 & 73 & 8 \\
\hline$>5 \mathrm{IHC}$ & 0 & 0 & 37 & 0 \\
\hline $5 \mathrm{OHC}$ & 20 & 0 & 46 & 3 \\
\hline$>5 \mathrm{OHC}$ & 0 & 0 & 36 & 0 \\
\hline Totals & 53 & 0 & 192 & 11 \\
\hline
\end{tabular}

Lesions are separated into categories based on type of cell, size of the lesion, and recovery time. Also, the total numbers of regenerated hair cells are listed.

possible time when they could be identified as committed to differentiate as hair cells. In nine out of 14 lesion sites made in embryonic organs of Corti, a noticeable gap in the row of inner hair cells persisted for at least $96 \mathrm{hr}$ after the laser irradiations. In five out of 14 lesion sites, inner hair cells that were adjacent to the lesion moved laterally to fill in the site after hair cell loss (Fig. 8). In one site of a lesion, a single inner hair cell was observed on the neural side of the existing row of inner hair cells $48 \mathrm{hr}$ after the laser treatment (Fig. 5B). However, there was lateral movement of surrounding inner hair cells adjacent to this lesion, suggesting that the presence of a second inner hair cell is probably the result of repositioning of existing hair cells. The morphology and relative maturity of this hair cell is similar to surrounding inner hair cells from undamaged regions of the epithelium, suggesting that it is unlikely that this cell developed as a replacement hair cell.

Recovery of the sensory epithelium in neonatal organs of Corti A total of 245 lesions (with an average of at least three hair cells per lesion) in 27 neonatal cochlear cultures were examined (Table 2). In order to investigate the response of the surrounding supporting cells after hair cell ablations, the apical borders of hair cells and supporting cells were labeled with rhodamineconjugated phalloidin (Raphael and Altschuler, 1991a,b). The initial response of the epithelium to the loss of hair cells was similar to the response of the epithelium after the loss of hair cells in vivo in adult cochleae (Bohne, 1976; Hunter-Duvar and Mount, 1978; Forge, 1985; Raphael and Altschuler, 1991a,b). When the laser-treated hair cells were extruded from the epithelium, the apical borders of the surrounding supporting cells expanded, filling in the area vacated by the dead hair cells. As a result, most lesion sites were initially repaired through the formation of phalangeal "scars" (Fig. 9A). However, in 73\% of inner hair cell lesion sites, the total number of cell surfaces that came to occupy the lesion site was higher than the number of supporting cells that should have remained after the removal of the hair cells. The increase in the number of cells was observed within the first 12-24 hr of recovery after the laser treatment (Fig. 9B). Similar increases in the number of cells in lesion sites were also observed in outer hair cell lesions, but at a lower frequency (34\%). The structure of this new type of phalangeal scar appeared to be stable, and similar scars were observed in lesion sites at least $7 \mathrm{~d}$ after laser treatments.

Autoradiographic data from cultures incubated in the presence of ${ }^{3} \mathrm{H}$-thymidine were examined to determine whether the new 

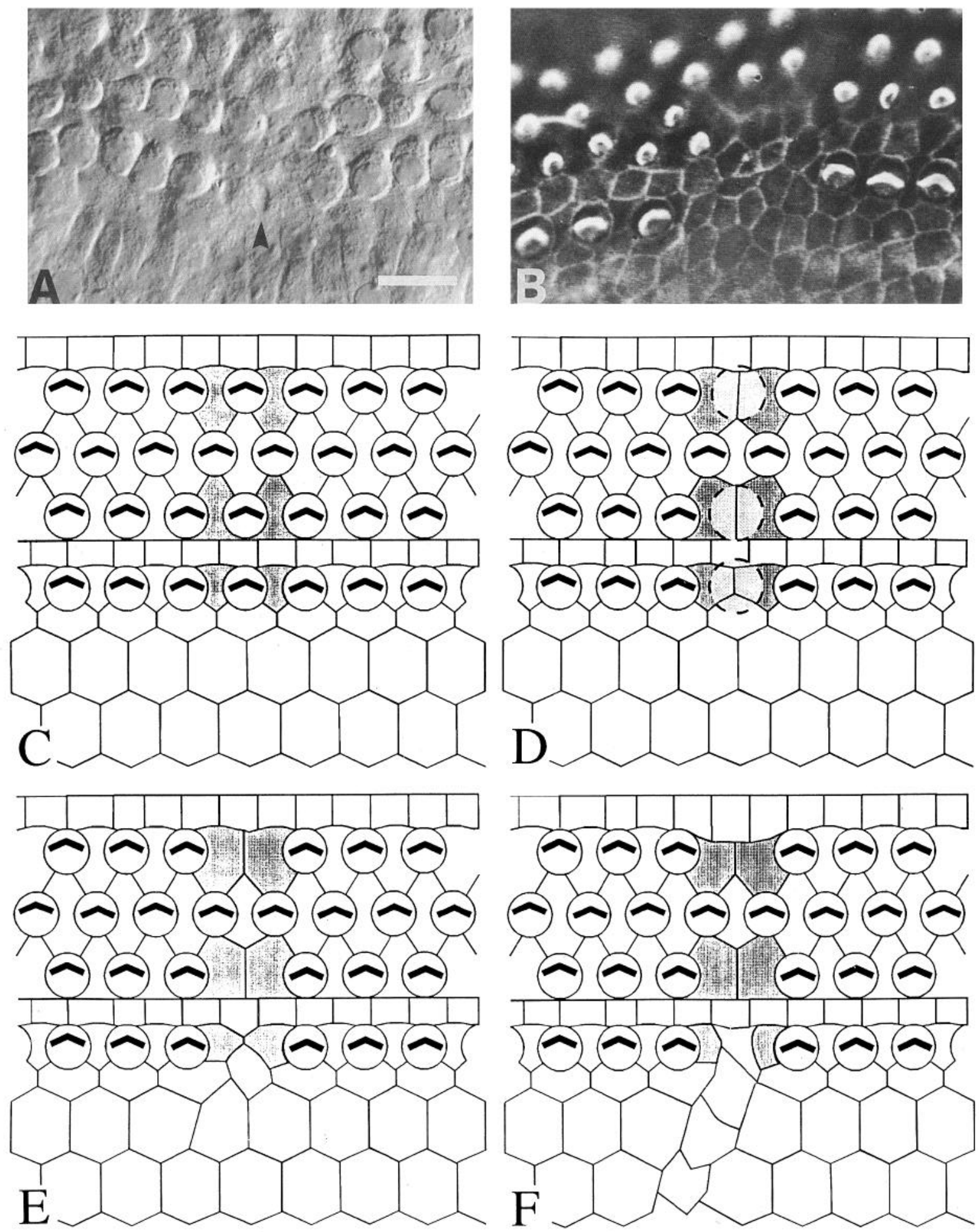

Figure 9. Response of the sensory epithelium in postnatal organ of Corti to hair cell death by laser irradiation. A, A DIC image of an outer hair cell lesion site $120 \mathrm{hr}$ after laser irradiation. The arrowhead marks the center of the lesion. B, A video-enhanced image of a phalloidin-labeled lesion site of two inner hair cells $24 \mathrm{hr}$ after irradiation. Note that there are approximately six cells in the lesion site. Since only two hair cells were ablated, the predicted number of cells between the two remaining inner hair cells would be only three. $C-F, \mathrm{~A}$ schematic drawing of the response of the sensory epithelium to the irradiation of a single inner hair cell, a single first row outer hair cell, and a single third row outer hair cell. After the extrusion of the irradiated hair cells, the surrounding supporting cells expand their apical borders to seal the epithelium. However, as recovery progresses, cells from outside of the sensory epithelium move into the lesion sites in the regions of the inner hair cell and, to a lesser extent, of the third row outer hair cell. Scale bar, $20 \mu \mathrm{m}$ for $A$ and $B$. 

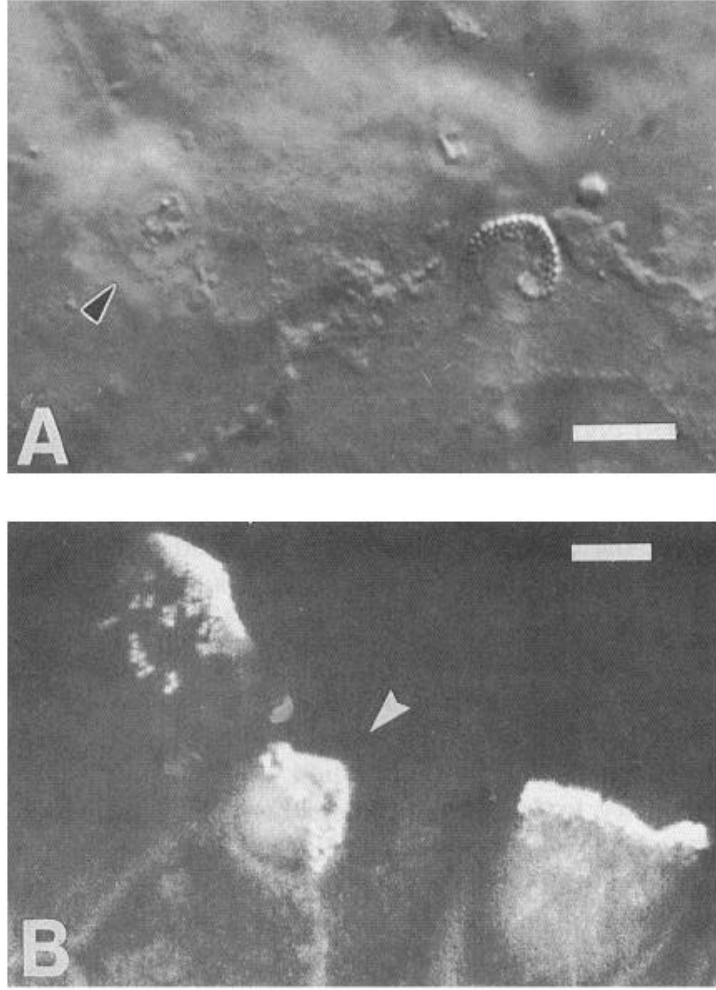

Figure 10. Regenerated hair cells in postnatal organ of Corti. A, A DIC image of an outer hair cell lesion site $96 \mathrm{hr}$ after laser irradiation. There is a cell with a small apical surface area and with a rounded ciliary bundle with a prominent kinocilium (arrowhead). Note the difference between the morphology of the bundle on this cell and the morphology of the stereociliary bundle of the cell next to it. $B$, A confocal three-dimensional image of an apparently immature hair cell ( $a r-$ rowhead) in an inner hair cell lesion site $56 \mathrm{hr}$ after laser irradiation Note that the cells on either side of the marked cell have stereociliary bundles with morphologies that are characteristic for mature inner hair cells. However, the morphology of the bundle on the marked cell appears more rounded, suggesting that it may be immature in comparison with its neighbors. Scale bars: $A 10 \mu \mathrm{m} ; B, 5 \mu \mathrm{m}$.

cells that were observed at inner hair cell lesion sites might have arisen through renewed proliferation. Analysis of 90 different lesions from 14 cochleae indicated that most of the new cells that were observed in inner hair cell lesion sites had not arisen through renewed proliferation within the sensory epithelium. However, in three lesion sites labeled cells were observed in the sensory epithelium. These cases will be discussed in the following section. Overall, the histological staining characteristics of the cells located in the lesion sites suggest that the new cells had moved into the lesion site from the epithelial cell population in the inner sulcus region of the organ of Corti, immediately adjacent to the hair cells on the neural (modiolar) side of the sensory epithelium (Fig. $9 C-F$ ).

Although most of the lesion sites that were analyzed did not appear to contain any regenerated hair cells, there were 11 cases where it appeared that hair cells may have been regenerated (Table 2). In each case, a cell with a small, rounded hair bundle and a small apical cell surface area was observed adjacent to a lesion site (Fig. 10). Based on the results of previous studies of the normal development of hair cells, these morphological characteristics are indicative of immature hair cells (Lim, 1977; Lim and Anniko, 1985; Mbiene and Sans, 1986). All of the poten-
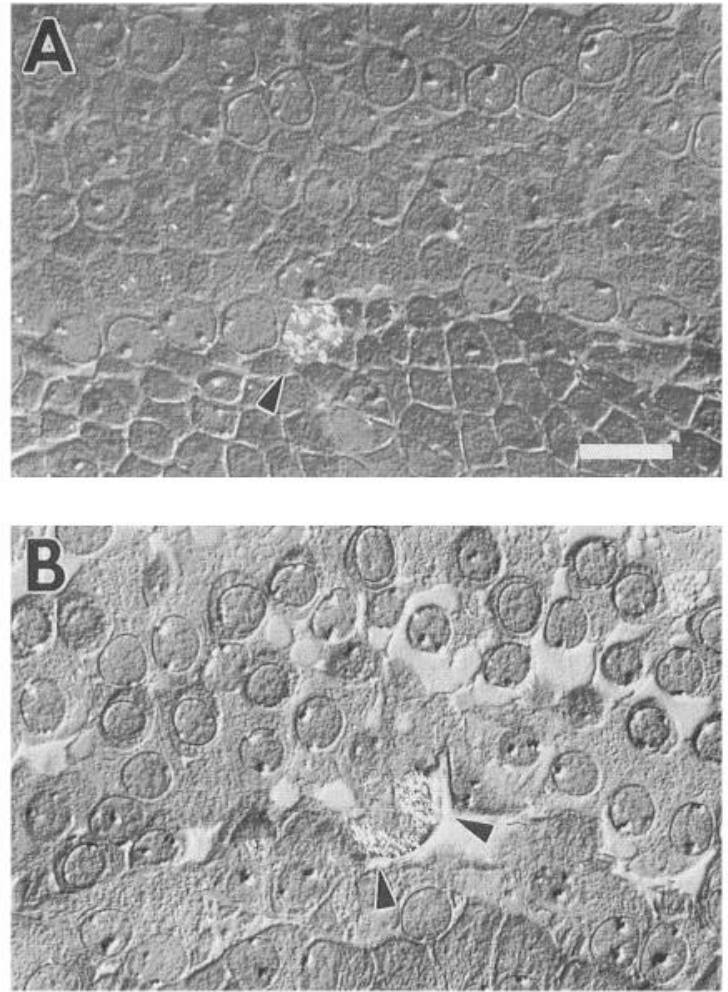

Figure 11. Autoradiographs of proliferative cells in postnatal organ of Corti. A, A single inner hair cell lesion site $72 \mathrm{hr}$ after hair cell ablation. There are silver grains over a single nucleus located adjacent to the lesion site (arrowhead). The morphology and position of this cell closely resemble the morphology and position of the surrounding inner hair cells. $B$, A single outer hair cell lesion site $120 \mathrm{hr}$ after laser irradiation. There are silver grains over two cells in the sensory epithelium that may be in the process of a mitotic division (arrowheads). Scale bar, 20 $\mu \mathrm{m}$ for $A$ and $B$.

tially regenerated hair cells were observed in lesion sites that had recovered for at least $3 \mathrm{~d}$ after the laser treatment. This observation is consistent with results from other studies, which indicate that new hair cells can first be identified $2-4 \mathrm{~d}$ after the initiation of hair cell trauma in the chick basilar papilla and by $3 \mathrm{~d}$ in amphibian lateral line neuromasts (Cotanche, 1987; Girod et al., 1989; Balak et al., 1990). Hair cells with immature morphologies were not observed in the undamaged regions of the laser-treated cochleae or in control organ cultures.

A single labeled, apparently regenerated hair cell was observed in one of the autoradiographs (Fig. 11A). In this case there were silver grains above a single cell nucleus located adjacent to an inner hair cell lesion. The histological staining of the nucleus and cytoplasm of the labeled cell was very similar to the staining of the neighboring hair cells. In addition, the labeled cell clearly differed from the supporting cells and the cells of the inner sulcus, in terms of its staining and its position in the epithelium. In another specimen, a dividing cell was observed in the middle of an outer hair cell lesion site (Fig. 11B). A total of four labeled cells were observed in or near lesion sites in the sensory epithelia. No labeled hair cells were observed in undamaged areas of the laser-treated organs or in control cultures.

\section{Discussion}

The results of these experiments indicate that there are limited capacities for spontaneous replacement of lost hair cells in em- 
bryonic and neonatal organs of Corti. In embryonic cochleae replacement hair cells arise from existing cells within the epithelium, rather than from new cells produced by cell division. These findings suggest that at least some cells in the developing sensory epithelium of the organ of Corti have the potential to specialize as either hair cells or supporting cells. Moreover, those cells which do not develop as hair cells retain a latent capacity to commit to that fate for approximately $48 \mathrm{hr}$ after committed hair cells begin to differentiate. It is important to note that all of these experiments were conducted in vitro, and it is possible that the response of the sensory epithelium would be different in vivo. However, cochlear cultures established using this technique closely follow the normal developmental pathway, strongly suggesting that the responses of the epithelium in vivo would be similar to the responses that were observed in vitro.

As the sensory epithelium develops, a critical period for cell phenotype determination appears to begin some time soon after terminal mitosis (E13-E15; Ruben, 1967) and extends for approximately 48-72 hr. The exact timing of the onset of this period is not yet known, because of the difficulty inherent in determining when a cell first becomes specified or committed to differentiate as a hair cell. For that reason the responses were tabulated in reference to the time when cells which had committed to become hair cclls first bccame recognizable bascd on their morphological differentiation. The period of prosensory cell determination in the organ of Corti extends from E14, in the base of the organ, to E16, in the apex (Kelley et al., 1993). Differentiating hair cells can first be identified based on morphologic characteristics on E15 in the base and on E17 in the apex. Therefore, it seems likely that initial hair cell commitment begins soon after prosensory cell determination and that the time between initial hair cell commitment and the beginning of recognizable morphological differentiation is approximately $24 \mathrm{hr}$. The observed appearance of recognizable replacement hair cells within $24 \mathrm{hr}$ of laser ablation is consistent with that time course for cell commitment and differentiation.

The results of these experiments indicate that the fates of cells in the developing organ of Corti are influenced by the cell's environment during the critical period for phenotype determination. However, the specific interactions or mechanisms that are required for the formation of the distinctive pattern of hair cells and supporting cells have not been experimentally demonstrated. Recently, theoretical models have been proposed that describe interactions that appear likely to control the formation of regularly spaced patterns of hair cells and supporting cells during normal development and during the reconstitution of pattern that results during regeneration (Corwin et al., 1991; Lewis, 1991). The models suggest that uncommitted cells within developing hair cell sensory epithelia essentially compete to become committed to the hair cell phenotype. Once an individual cell has become committed to differentiate as a hair cell, that cell then exerts a form of lateral inhibition on any neighboring cells that it contacts, so that the immediate neighbors of hair cells are prevented from differentiating as hair cells. Those inhibited cells are constrained to differentiate as supporting cells. Lateral inhibitory mechanisms similar to this are known to play key roles in the development of other regularly spaced patterns, for instance in the development of sensory bristles in Drosophila (Wigglesworth, 1940; Claxton, 1964, 1967; Vassin et al., 1985; Hoppe and Greenspan, 1986; de la Concha et al., 1988).

What would be the developmental fates of the cells that differentiate as replacement hair cells at lesion sites if they were to develop in an undisturbed epithelium? It may be that these cells would have developed as some types of supporting cells or they could have been destined for programmed cell death. In the time-lapse recordings some evidence was observed that was consistent with the potential occurrence of a period of cell death within the normally developing cochlear sensory epithelia at E17. Evidence for a period of cell death in the developing cochlea has also been reported in other studies (Sher, 1971; Lim and Anniko, 1985). One hypothesis suggests that there may be an overproduction of prosensory cells at an early stage in the development of the sensory epithelium followed by a period of programmed cell death, occurring after all hair cells have become specified and have begun to differentiate. Although this hypothesis as applied to the sensory epithelium itself has not been tested, there is clear evidence for periods of programmed cell death affecting other elements of the cochlea, including neurons and the inner sulcus epithelial cells (Hinojosa, 1977; Rueda et al., 1987). It seems possible that the presumably unspecialized cells which changed fate in these experiments might have died during a subsequent period of programmed cell death if the preexisting hair cells had not been killed.

'Ihe capacity to form replacement hair cells in the organ of Corti after laser irradiations was limited to a finite period in development. On the basis of current evidence it is not possible to explain why the response of the epithelium changed. It is possible that as a result of cell death or cell migration, the number of uncommitted cells in the epithelium decreased over time. Alternatively, it is possible that as the organ of Corti developed, all of the cells in the epithelium became irreversibly committed to specific cell fates.

The response of the epithelium after cells that were committed to differentiate as inner hair cells were ablated was markedly different from the response of the epithelium to the death of outer hair cells. However, it is potentially significant that inner hair cells differentiate prior to outer hair cells at the same location in the cochlea (Kikuchi and Hilding, 1965; Lim and Anniko, 1985). It seems likely that the remaining nonsensory cells in the inner hair cell region had either already become irreversibly committed to specific cell fates or might have already passed through a stage of cell death, at the time when inner hair cells were killed by the laser microbeam. We can only speculate that if it were possible to individually identify and kill inner hair cell precursors earlier in development, then a response might occur that would be similar to the replacement responses that were observed after outer hair cell losses.

The observation that the capacity to develop replacement hair cells ends in the basal half of the developing organ of Corti 2 $\mathrm{d}$ before it ends in the apical half of the organ suggests that cell commitment may follow the same spatiotemporal developmental pattern as cell differentiation. As discussed, the differentiation of the organ of Corti occurs as a wave that starts near the base of the cochlea and proceeds towards the apex (Kikuchi and Hilding, 1965; Lim and Anniko, 1985). The specification or determination of prosensory cells as indicated by the responsiveness to retinoic acid treatments, occurs prior to determination of individual cell phenotype, and also progresses from base to apex (Kelley et al., 1993). Based on the results presented in this report and on previous work from our laboratory (Kelley et al., 1993), it seems likely that the specification and eventual determination of individual hair cell and supporting cell phenotypes in the cochlea occurs through three sequential processes. First, a population of prosensory cells that become competent to differen- 
tiate as either hair cells or supporting cells is defined. Next, individual cell fates (i.e., as hair cells and supporting cells) become specified and then determined through lateral inhibitory cell-cell interactions. Then the individual cells differentiate, expressing their specific phenotypes. Each process occurs along a basal-to-apical gradient, with all of the processes timed closely. Therefore, it is possible for the onset of one process in the base to overlap in time with the completion of the preceding developmental process in the apex (Kelley et al., 1993).

The observations of limited numbers of proliferative cells and rare apparently regenerated hair cells in cochlear cultures established from neonatal mice suggest that hair cell regeneration can occur in postnatal organs of Corti in a simple organ culture environment as a spontaneous response to hair cell death. The number of putative regenerated hair cells observed was small (less than $1 \%$ of the total number of hair cells that were ablated), but it could be argued that the development of any regenerated hair cells is significant under the circumstances. The rare occurrence of regeneration indicates that the cell signalling and response mechanisms that are required for hair cell regeneration are able to persist in the organ of Corti beyond the period of embryonic hair cell development. At least one of the putative regenerated hair cells was labeled by tritiated thymidine administered after the laser treatment, suggesting that some of the neighboring cells which were more commonly observed to proliferate in these cultures in response to hair cell ablations may be capable of giving rise to new, replacement hair cells. Hair cell regeneration was a rare event in these experiments, and in that regard the results were markedly different from the nearly complete restoration of normal numbers of hair cells that was recently reported to occur in retinoic acid-treated organ cultures of neonatal rat cochleae after destruction of the hair cells by exposure to neomycin (Lefebvre et al., 1993).

\section{References}

Balak KJ, Corwin JT, Jones JE (1990) Regenerated hair cells can originate from supporting cell progeny: evidence from phototoxicity and laser ablation experiments in the lateral line system. J Neurosci 10:2502-2512.

Bohne BA (1976) Healing of the noise damaged inner ear. In: Hearing and Davis: essays, pp 85-96. St. Louis: Washington UP.

Claxton JH (1964) The determination of patterns with special reference to that of the central primary skin follicles in sheep. $J$ Theor Biol 7:302-317.

Claxton JH (1967) Patterns of abdominal tergite bristles in wild-type and scute Drosophila melanogaster. Genetics 55:525-545.

Corwin JT (1985) Perpetual production of hair cells and maturational changes in hair cell ultrastructure accompany postembryonic growth in an amphibian ear. Proc Natl $\Lambda$ cad Sci US $\Lambda$ 82:39113915.

Corwin JT (1986) Regeneration and self-repair in hair cell epithelia: experimental evaluation of capacities and limitations. In: The biology of change in otolaryngology (Ruben RJ, Van De Water TR, Rubel EW, eds), pp 291-304. Amsterdam: Elsevier.

Corwin JT, Cotanche DA (1988) Regeneration of sensory hair cells after acoustic trauma. Science 240:1772-1774.

Corwin JT, Jones JE, Katayama A, Kelley MW, Warchol ME (1991) Hair cell regeneration: the identities of progenitor cells, potential triggers and instructive cues. In: Regeneration of vertebrate sensory receptor cells (Bock G, Whelan J, eds), pp 103-119. New York: Wiley.

Cotanche DA (1987) Regeneration of hair cell stereociliary bundles in the chick cochlea following severe acoustic trauma. Hearing Res 30:181-194.

de la Concha A, Dietrich U, Weigel D, Compos-Ortega JA (1988) Functional interactions of neurogenic genes of Drosophila melanogaster. Genetics 118:499-508.
Forge A (1985) Outer hair cell loss and supporting cell expansion following chronic gentamicin treatment. Hearing Res 19:171-182.

Forge A, Li L, Corwin JT, Nevill G (1993) Ultrastructural evidence for hair cell regeneration in the mammalian inner ear. Science 259 : $1616-1619$.

Girod DA, Duckert LG, Rubel EW (1989) Possible precursors of regenerated hair cells in the avian cochlea following acoustic trauma. Hearing Res 42:175-194.

Hinojosa R (1977) A note on development of Corti's organ. Acta Otolaryngol (Stockh) 84:238-251.

Hoppe PE, Greenspan RJ (1986) Local function of the Notch gene for embryonic ectodermal pathway choice in Drosophila. Cell 46: $773-783$.

Hunter-Duvar IM, Mount RJ (1978) The organ of Corti following ototoxic antibiotic treatment. Scanning Electron Microsc II:423430.

Kelley MW, Laverack CM, Corwin JT (1991) Recovery of the mammalian organ of Corti after laser microbeam ablation of embryonic hair cells. Soc Neurosci Abstr 17:631.

Kelley MW, Xu X-M, Wagner MA, Warchol ME, Corwin JT (1993) The developing organ of Corti contains retinoic acid and forms supernumerary hair cells in response to exogenous retinoic acid in culture. Development 119:1041-1053.

Kikuchi K, Hilding D (1965) The development of the organ of Corti in the mouse. Acta Otolaryngol (Stockh) 60:207-222.

Lefebvre PP, Malgrange B, Staecker H, Moonen G, Van De Water TR (1993) Retinoic acid stimulates regeneration of mammalian auditory hair cells. Science 260:692-695.

Lewis J (1991) Rules for the production of sensory cells. In: Regeneration of vertebrate sensory receptor cells (Bock $G$, Whelan J, eds), pp 25-39. New York: Wiley.

Lim DJ (1977) Fine morphology of the tectorial membrane: fresh and developmental. INSERM Symp 68:47-60.

Lim DJ, Anniko M (1985) Developmental morphology of the mouse inner ear. Acta Otolaryngol [Suppl] (Stockh) 422:1-69.

Lim DJ, Rueda J (1992) Structural development of the cochlea. In: Development of the auditory and vestibular systems 2 (Romand R, ed), pp 33-58. New York: Elsevier.

Lombarte A, Yan HY, Popper AN, Chang JS, Platt C (1993) Damage and regeneration of hair cell ciliary bundles in a fish ear following treatment with gentamicin. Hearing Res 64:166-174.

Mbiene JP, Sans A (1986) Differentiation and maturation of the sensory hair bundles in the fetal and postnatal vestibular receptors of the mouse: a scanning electron microscopy study. J Comp Neurol 254:271-278.

Raphael Y, Altschuler RA (1991a) Reorganization of cytoskeletal and junctional proteins during cochlear hair cell degeneration. Cell Motil Cytoskel 18:215-227.

Raphael Y, Altschuler RA (1991b) Scar formation after drug-induced cochlear insult. Hearing Res 51:173-183.

Ruben RJ (1967) Development of the inner ear of the mouse: a radioautographic study of terminal mitoses. Acta Otolaryngol [Suppl] (Stockh) 220:1-44.

Rueda J, De la Sen C, Juiz JM, Merchan JA (1987) Neuronal loss in the spiral ganglion of young rats. Acta Otolaryngol (Stockh) 104: 417-421.

Ryals BM, Rubel EW (1988) Hair cell regeneration after acoustic trauma in adult Cortunix quail. Science 240:1774-1776.

Sher AE (1971) The embryonic and postnatal development of the inner ear of the mouse. Acta Otolaryngol [Suppl] (Stockh) 285:177.

Sobkowicz HM, Bereman B, Rose J (1975) Organotypic development of the organ of Corti in culture. J Neurocytol 4:432-572.

Sobkowicz HM, Loftus JM, Slapkick SM (1993) Tissue culture of the organ of Corti. Acta Otolaryngol [Suppl] (Stockh) 502:3-36.

Stone LS (1937) Further experimental studies of the development of lateral-line sense organs in amphibians observed in living preparations. J Comp Neurol 68:83-115.

Theiler K (1972) The house mouse: developmental and normal stages from fertilization to 4 weeks of age. New York: Springer.

Vassin H, Vielmetter J, Campos-Ortega JA (1985) Genetic interactions in early neurogenesis of Drosophila melanogaster. J Neurogenet 2:291-308.

Warchol ME, Lambert PR, Goldstein BJ, Forge A, Corwin JT (1993) 
Regenerative proliferation in inner ear sensory epithelia from adult guinea pigs and humans. Science 259:1619-1622.

Weisleder P, Rubel EW (1992) Hair cell regeneration in the avian vestibular epithelium. Exp Neurol 115:2-6.

Wigglesworth VB (1940) Local and general factors in the develop- ment of "pattern" in Rhodnius prolixus (Hemiptera). J Exp Biol $17: 180-200$.

Wulf E, Deboben A, Bautz FA, Faulstich H, Wieland T (1979) Fluorescent phallotoxin, a tool for the visualization of cellular actin. Proc Natl Acad Sci USA 76:4-4502. 